\title{
Rights Share Issue Practice in Nepal
}

\section{Hari Prasad Pathak \& Dhanesh Giri}

\begin{abstract}
The study is focused on practice of rights offering in Nepal and its impact on share price movement. This study covers two interrelated aspects: (a) Characteristics of rights offering of listed companies and (b) Share price movement associated with rights offering. Nepal Finance and Saving Company Ltd. started the practice of rights share in Nepal by issuing right share for the first time in $1^{\text {st }}$ December 1995. In this study, the rights share issue practice and impact of rights offering on market price of share have been analyzed by taking five rights issuing companies as sample. The findings of the study are not consistent with the theory of rights offering.
\end{abstract}

Key Words: Rights share, share price movement, share price index (NEPSE index)

\section{Introduction}

Every firm needs adequate capital to perform efficiently. Generally, firms fulfill their financial requirement by issuing equity share, preference share, debentures and long term bonds. Rights issue is one of the instruments to raise additional capital. We can describe the preemptive right or rights as the privilege offered to existing stockholders for buying specified number of additional shares of the company's stock before the stock is offered to outsiders for sale. They have value because generally they are offered at a subscription price somewhat lower than the market price of share. In the secondary market, investors are willing to buy the share that has been attached to the preemptive right. But to buy additional number of shares, the shareholder should have his/her name in company's book before the record date. Hence before the record date, there will be a great demand of share attached with rights. Demand is increased because large numbers of people rush to secondary market in order to enlist their name in the company's book before record date so that they can enjoy the benefits of right offering. On the other hand, existing shareholders generally have no willingness to sell the shares to exercise the rights. Due to this double pressure, the price of share goes upwards.

Theoretically price of share increases after rights offering and decreases after the issue of right share but some practical cases in Nepalese companies have mixed results in this regard. Nepal Finance and Saving Company Ltd. announced issue of right share for the 
first time (December 1, 1995) when market price of its share was constant at Rs. 110 for two months before announcement. But after announcement, there was only one transaction before the record date that even at a price below its previous market price. Ace Finance Company Ltd. is another example whose stock price was Rs. 410 before the announcement but after announcement there was no transaction at all before the record date. Necon Air's stock was priced at Rs. 309 before the right share announcement but it grew up to Rs. 366 after the announcement. This is the case that follows the price movement consistent with the theory that rights offering announcement appreciates the price of the share. Share prices of the majority companies were decreased after the rights share announcement and decreased rapidly after allotment. Only few companies met the theory.

The following table shows the contribution of rights issue in the total public floatation in each fiscal year in which rights issue had taken place.

Table 1 : Share of Rights Issue on Total Public Flotation (Rs. In Million)

\begin{tabular}{|c|r|r|r|r|}
\hline FY(A) & $\begin{array}{c}\text { Total Public } \\
\text { Floatation (B) }\end{array}$ & $\begin{array}{c}\text { Number of Rights } \\
\text { Offering (C) }\end{array}$ & $\begin{array}{c}\text { Total Amount Raised } \\
\text { Through Rights Offering } \\
\text { (D) }\end{array}$ & D as \% of B \\
\hline $2052 / 53$ & 293.74 & 2 & 69.00 & $23.49 \%$ \\
\hline $2053 / 54$ & 332.20 & 3 & 275.20 & $82.84 \%$ \\
\hline $2054 / 55$ & 462.36 & 3 & 249.96 & $54.06 \%$ \\
\hline $2055 / 56$ & 258.00 & 1 & 30.00 & $11.63 \%$ \\
\hline $2056 / 57$ & 326.86 & 3 & 184.60 & $56.48 \%$ \\
\hline $2057 / 58$ & 410.49 & 2 & 131.79 & $32.11 \%$ \\
\hline $2058 / 59$ & 1441.33 & 5 & 885.45 & $61.43 \%$ \\
\hline $2059 / 60$ & 556.54 & 4 & 162.24 & $29.15 \%$ \\
\hline $2060 / 61$ & 1027.50 & 3 & 70.00 & $6.81 \%$ \\
\hline $2061 / 62$ & 1626.82 & 6 & 949.34 & $58.36 \%$ \\
\hline $2062 / 63$ & 2443.28 & 11 & 1013.45 & $41.48 \%$ \\
\hline $2063 / 64$ & 11893.20 & 17 & 1265.30 & $10.64 \%$ \\
\hline Total & $\mathbf{2 1 0 7 2 . 3 2}$ & $\mathbf{6 0}$ & $\mathbf{5 2 8 6 . 3 3}$ & $\mathbf{2 5 . 0 9 \%}$ \\
\hline
\end{tabular}

Source: Annual Report of SEBO/N, 2006/07

It is clear from above table that in the preliminary stage, the trend of rights offering in Nepalese share market was quite low. In the fiscal year 2052/53, there were two cases of rights offering in which the share of rights offering was $23.49 \%$ of the total public floatation. Similarly in the fiscal year 2053/54, 3 companies issued rights share amounting Rs. 275.20 million out of Rs. 332.20 million of total public floatation. Observing the above data, we 94 
can easily conclude that the share of rights offering on total public floatation was highest during the fiscal year 2053/54. In the fiscal year 2054/55, out of Rs. 462.36 Million of total public floatation, Rs. 249.96 million was raised through rights offering. In the fiscal year $2055 / 56$, the contribution of rights share on total public floatation was just $11.63 \%$ i.e. Rs. 30 million out of Rs. 258 million of total public floatation. In FY 2056/57, three companies issued right share. The proportion of rights share was $56.48 \%$ i.e 184.60 million out of Rs 326.86 million of total public floatation. In that fiscal year, Necon Air, Paschimanchal Finance Company Ltd and Ace Finance Co. Ltd issued right share. Similarly Narayani Finance Ltd and Everest Bank Ltd issued right share in the FY 2057/58. The proportion of right share was $61.43 \%$ in the FY 2058/59. In the FY 2059/60, there were 4 cases of rights offering of Rs. 162.24 million which covers $29.15 \%$ of total public floatation of Rs. 556.54 Million.

In the FY 2060/61, three companies namely Alpic Everest Finance Ltd, Siddhartha Finance Ltd, NB Finance and Leasing company issued rights share of Rs. 70 million i.e 6.81\% of Rs. 1027.50 million of total public floatation. The issuance of right share seems quite low in this fiscal year. Altogether 6 companies issued right share in FY 2061/62 amounting Rs. 949.34 million which is $58.36 \%$ of total public floatation of Rs. 1626.82 million. In FY 2063/64, 17 companies issued right share. The proportion of rights share was $10.64 \%$ i.e. Rs. 1265.30 million out of Rs. 11893.20 million of total public floatation. After analyzing the table, it is clear that during the FY 2060/61, there is lower percentage of rights offering i.e. $6.81 \%$ in comparison to other fiscal years. The lowest amount of rights offering was in FY 2055/56 and highest amount of rights offering was in FY 2063/64. This was because of the NRB directives that the financial institutions have to maintain optimal capital adequacy ratio. So most of the financial institutions had to raise their capital and they issued right share.

This study is mainly focused on the right share issue practice in Nepal and the impact of rights offering announcement in the market price of share. This study is helpful to investors, security dealers, students and the companies themselves which are the samples of the study. It helps these parties to know about the share price movement after the issue of right share.

\section{Research Methodology}

Data used for this study were collected mostly from secondary sources including the records available with the $\mathrm{SEBO} / \mathrm{N}$, annual reports of respective companies and the directories of the stock exchange. The share prices were collected from the official quotation list of NEPSE published in the national daily newspapers such as Kantipur, Gorkhapatra, and The Kathmandu Post as well as trading report of NEPSE. Besides these, primary data 
were collected through questionnaires and interview.

Basically this study covers those companies which are listed in NEPSE and have issued rights share. In addition, this study covers the data of five years period. The research throws light on several aspects of the corporate financial policies and practices regarding rights offering such as subscription price, subscription ratio, total issue Vs total subscription of rights share, frequency of the rights offering by an individual company and legal provisions regarding the rights offering.

As per the annual report of SEBO/N for FY 2006/07, there are 135 listed companies in the Nepal Stock Exchange categorized under different sectors. Among them, only 46 companies have issued rights share till FY 2006/07. All the listed companies that have issued rights share have been taken as population. The major portion of Nepalese securities market is controlled by banks, finance companies and insurance companies. Any fluctuations in those companies' share price directly affects NEPSE index. Stratified Random Sampling method has been used for this study. Five right issuing companies have been taken as sample to conduct the research. They consist of three from banks and two from finance companies. To complete this study, the researcher has conducted correlation analysis as a statistical tool. The Karl Pearson's method, popularly known as Pearson's coefficient of correlation is most widely used in practice. The formula for computing Pearson's correlation coefficient(r) using direct method is as follows.

$$
r=\frac{N \sum X Y-\sum X \sum Y}{\sqrt{N \sum X^{2}-\left(\sum X\right)^{2}} \sqrt{N \sum Y^{2}-\left(\sum Y\right)^{2}}}
$$

Where,

$\mathrm{X}=$ Share Price

$\mathrm{Y}=$ NEPSE indices for total equity capital

$\mathrm{r}=$ Correlation Coefficient

To test out research hypothesis, t-statistics is used here. T-statistics has been used to test the significance of the differences between the share price before and after the announcement of the rights offering by the companies. Here the researcher has used paired t-test.

$$
\begin{aligned}
\mathrm{S}^{2} & =\frac{\sum(\mathrm{X}-\overline{\mathrm{X}})+\sum(\mathrm{Y}-\overline{\mathrm{Y}})}{\mathrm{n}_{1}+\mathrm{n}_{2}-2} \\
\mathrm{t}_{\mathrm{cal}} & =\frac{\overline{\mathrm{X}}-\overline{\mathrm{Y}}}{\sqrt{\mathrm{S}^{2}\left(\frac{1}{\mathrm{n}_{1}}+\frac{1}{\mathrm{n}_{2}}\right)}}
\end{aligned}
$$


Where,

$\mathrm{X}=$ Price index of total equity capital before announcement

$\mathrm{Y}=$ Price index of total equity capital after announcement

$\mathrm{n}=$ Number of observation

$\mathrm{t}_{\text {cal }}=$ Calculated value of $\mathrm{t}$

$\mathrm{S}^{2}=$ An unbiased estimate of the common population variance $\sigma^{2}$ based on both the samples Valuation of rights is very important to analyze the share price movement. After the closing date of rights share offering, share price will drop to the extent of value of right.

Value of One Right $=\frac{P_{o}-S}{\#+1}$

Where,

Po $=$ Current market price of share

$\mathrm{S} \quad=$ Subscription Price

\# $\quad=$ Number of rights required to purchase one new share

\section{Analysis of share price movement before and after the rights offering}

Five different points of time have been selected for observing the price movement with the announcement date as the point of reference. The selected points of time are:

1. Three months before the rights announcement date as base date

2. Ten days before the announcement date

3. Day of the rights announcement

4. Seven days after the announcement

5. Six months after the announcement

The price movements of a total of five companies including banks and financial institutions namely Nepal Bank Ltd(NBL), Nepal Investment Bank Ltd(NIBL), Bank of Kathmandu Ltd(BOK), People Finance Limited(PFL) and NIDC Capital Markets Ltd(NCML) have been taken as sample for the study purpose.

Table 2 : Movement of Share Price

\begin{tabular}{|c|c|c|c|c|c|}
\hline $\begin{array}{c}\text { Share } \\
\text { Price }\end{array}$ & $\begin{array}{c}90 \text { Days Before } \\
\text { Announcement }\end{array}$ & $\begin{array}{c}\text { 10 Days Before } \\
\text { Announcement }\end{array}$ & $\begin{array}{c}\text { The Day of } \\
\text { Announcement }\end{array}$ & $\begin{array}{c}7 \text { Days After } \\
\text { Announcement }\end{array}$ & $\begin{array}{c}\text { 180 Days After } \\
\text { Announcement }\end{array}$ \\
\hline NBL & 470 & 480 & 370 & 370 & 380 \\
\hline NIBL & 1170 & 1331 & 801 & 880 & 831 \\
\hline BOK & 1015 & 801 & 815 & 460 & 315 \\
\hline PFL & 105 & 95 & 95 & 95 & 95 \\
\hline NCML & 400 & 410 & 410 & 220 & 180 \\
\hline
\end{tabular}


In the above table, we can see the price movement of share price of Nepal Bank Ltd (NBL) at different points of time. The share price is Rs. 470 three months before the announcement date and reached to Rs. 480 with the announcement and afterwards the price reduced to Rs. 370. Similarly, share price of Nepal Investment Bank Ltd (NIBL) increased from Rs. 1170 to Rs. 1331 from base date to ten days before the announcement date. The price was Rs. 801 at the day of announcement whereas it is Rs. 880 after 7 days and Rs. 831 after six months of rights share issue. Actual share price of Bank of Kathmandu (BOK) decreased from Rs. 1015 to Rs. 801 from base date to ten days before announcement date. It was Rs. 815 on the day of announcement where it was Rs. 460 seven days after announcement and Rs. 315 six month after announcement. This shows that there was a hasty decrease in the actual price except on the day of announcement. The share price of People's Finance Ltd (PFL) is decreased from Rs. 105 to Rs. 95 ten days before announcement date i.e. less than par value. The share price was Rs. 95 at the day of rights announcement and it remained unchanged after seven days and six months of announcement. Before three months of announcement, share price of NIDC Capital Market is Rs. 400 and it rose up to Rs. 410 before 10 days of announcement. But after seven days of rights issue, there is extreme decline in NIDC's share from Rs. 410 to Rs. 220. After six months, the price fell down to Rs. 180, a commendable reduction in price.

\section{Correlation coefficient between share price movement and general market movement during five different points of time}

In practice, general market movement also affects the share price. So it is indeed important to study correlation between the share price movement of sample organizations and general market movement. It is seen in practice that sometimes not only rights offering but also general market movement cause the declination in share price. After calculating correlation between share price movements of sample organizations and general market movement following results have been obtained.

Table 3 : Correlation between share price movements of sample organizations and general market movement

\begin{tabular}{|l|r|r|}
\hline \multicolumn{1}{|c|}{ Sample Organization } & Correlation Coefficient & $\begin{array}{c}\text { Coefficient of } \\
\text { Determination }\end{array}$ \\
\hline Nepal Bank Ltd. & 0.2170 & 0.0471 \\
\hline Nepal Investment Bank Ltd & -0.3987 & 0.1590 \\
\hline Bank of Kathmandu Ltd & 0.8925 & 0.7965 \\
\hline People's Finance Co. Ltd & -0.4915 & 0.2416 \\
\hline NIDC Capital Markets Ltd. & 0.0257 & 0.0006 \\
\hline
\end{tabular}


From the above table we can conclude that there is lower degree of positive correlation i.e. 0.2170 between share price movement and general market movement in the case of Nepal Bank Ltd. Similarly coefficient of determination of Nepal Bank Ltd is 0.0471 which indicates that the general market movement has only $4.71 \%$ role in the share price behaviour of NBL and rest is by other unforeseeable factors. In case of Nepal Investment Bank Ltd, correlation between NIB share and general market movement is in negative figure so there is no positive correlation between the general market movement and share price of NIB. General market movement explains only $15.90 \%$ variation in the share price of NIB which is represented by the coefficient of determination. The case of Bank of Kathmandu is quite different than that of NBL and NIB. Correlation coefficient between the share price and general market movement is calculated as 0.8925 which indicates that there is high degree of positive correlation between share price and general market movement. Correlation coefficient between the share price of People's Finance Company Limited and general market movement is highly negative. It means there is no significant relation between the share price of PFCL and general market movement. Similarly, coefficient of determination is 0.2416 which indicates that the general market movement has contributed $24.16 \%$ to determine the share price of People's Finance Company Ltd and the rest is determined by other factors. In case of NIDC Capital Markets' stock, there is positive but low degree of correlation between its share price movement and general market movement.

\section{Findings of the study}

a) The trend of issuing rights share is increasing in Nepalese capital market.

b) There are a large number of shareholders who are holding small quantities of share.

c) Price behaviors shown by the stock of sample organizations do not satisfy the theory of rights offering.

d) Most of the investors like to invest in banking and financial organizations.

e) More than $50 \%$ investors like to subscribe rights share just to increase the number of shares.

f) Existing legal provision is not adequate and needs to be amended as soon as possible.

g) The under-subscription of rights share is caused by various factors such as lack of investor's awareness, low performance of companies and lack of adequate information. Among these factors, lack of adequate information to shareholders is major. 


\section{References}

Baral, D.R. (2002). “Stock Price Movement in Nepal.,” Master diss., Shankar Dev Campus, TU.

Chaudhary, A.K. and P.K. Sharma. (2003). Statistical Methods. Kathmandu: Khanal Books Prakashan.

Gautam, R.R. and Kiran Thapa. (2004). Capital Structure Management. Kathmandu: Asmita Books and Distributors.

Kerlinger, Fred N. (1978). Foundation of Behavioural Research. New Delhi: Surjit Publication.

Kothari, C.R. (1994). Quantitative Techniques. New Delhi: Vikash Publishing House.

Marsh and Paul. “UK Rights Issue.” The Journal of Finance, Vol. 20. (1980):

Nepal Rastra Bank. [Online]: www.nrb.org.np

Nepal Rastra Bank. (2008). Banking and Financial Statistics. Kathmandu: Nepal Rastra Bank.

NEPSE. [Online]: www.nepalstock.com

Ojha, Khagendra P. (2058). "Financial Performances and Common Stock Pricing." Master diss., Shankar Dev Campus, TU.

Pandey, I.M. (1999). Financial Management. New Delhi: Vikash Publishing House.

Pant, Prem R. and Howard K. Wolff. (2004). Social Science Research and Thesis Writing. Kathmandu: Buddha Academic Publishers and Distributors Pvt. Ltd.

Pradhan, R.S. (2004). Financial Management. Kathmandu: Buddha Academic Publishers and Distributors Pvt. Ltd.

SEBO/N [Online]: www.sebonp.com

Securities Board of Nepal. (2004). Security Board of Nepal- A Ten Year Performance (1993-2003), Kathmandu: SEBO Publication.

Securities Board of Nepal. (2007). Annual Report. Kathmandu: Securities Board of Nepal.

Sharpe, William F., Gordon J. Alexander, and Jeffery V. Bailey. (2003). Investment. New Delhi: Prentice Hall of India Ltd.

Vanhorne, James C. (1999). Financial Management and Policy. New Delhi: Prentice Hall of India.

Weston, J.F. and E.F. Brigham. (1992). Managerial Finance. Hinsdale Illinois: The Dryden Press. 